\title{
Proximate and ultimate controls on carbon and nutrient dynamics of small agricultural catchments
}

\author{
Zahra Thomas ${ }^{1, *}$, Benjamin W. Abbott ${ }^{2, *}$, Olivier Troccaz ${ }^{2}$, Jacques Baudry $^{3}$, and Gilles Pinay ${ }^{2}$ \\ ${ }^{1}$ AGROCAMPUS OUEST, INRA, SAS, 35000 Rennes, France \\ ${ }^{2}$ ECOBIO, OSUR, CNRS, Université de Rennes 1, Campus de Beaulieu, 35000 Rennes, France \\ ${ }^{3}$ INRA, UR 980, SAD-Paysage, 35000 Rennes, France \\ *These authors contributed equally to this work.
}

Correspondence to: Zahra Thomas (zthomas@agrocampus-ouest.fr)

Received: 27 June 2015 - Published in Biogeosciences Discuss.: 17 September 2015

Revised: 25 February 2016 - Accepted: 9 March 2016 - Published: 30 March 2016

\begin{abstract}
Direct and indirect effects from human activity have dramatically increased nutrient loading to aquatic inland and estuarine ecosystems. Despite an abundance of studies investigating the impact of agricultural activity on water quality, our understanding of what determines the capacity of a watershed to remove or retain nutrients remains limited. The goal of this study was to identify proximate and ultimate controls on dissolved organic carbon and nutrient dynamics in small agricultural catchments by investigating the relationship between catchment characteristics, stream discharge, and water chemistry. We analyzed a 5-year, high-frequency water chemistry data set from three catchments in western France ranging from 2.3 to $10.8 \mathrm{~km}^{2}$. The relationship between hydrology and solute concentrations differed between the three catchments and was associated with hedgerow density, agricultural activity, and geology. The catchment with thicker soil and higher surface roughness had relatively invariant carbon and nutrient chemistry across hydrologic conditions, indicating high resilience to human disturbance. Conversely, the catchments with smoother, thinner soils responded to both intra- and interannual hydrologic variation with high concentrations of phosphate $\left(\mathrm{PO}_{4}^{3-}\right)$ and ammonium $\left(\mathrm{NH}_{4}^{+}\right)$in streams during low flow conditions and strong increases in dissolved organic carbon (DOC), sediment, and particulate organic matter during high flows. Despite contrasting agricultural activity between catchments, the physical context (geology, topography, and land-use configuration) appeared to be the most important determinant of catchment solute dynamics based on principle components analysis. The influence of geology and accompanying topo-
\end{abstract}

graphic and geomorphological factors on water quality was both direct and indirect because the distribution of agricultural activity in these catchments is largely a consequence of the geologic and topographic context. This link between inherent catchment buffering capacity and the probability of human disturbance provides a useful perspective for evaluating vulnerability of aquatic ecosystems and for managing systems to maintain agricultural production while minimizing leakage of nutrients.

\section{Introduction}

Direct and indirect effects from agriculture, urbanization, and resource extraction have dramatically increased nutrient loading to aquatic inland and estuarine ecosystems. In the past 60 years, human activity has more than doubled global nitrogen fixation (Gruber and Galloway, 2008) and quadrupled phosphorus loading (Elser and Bennett, 2011), primarily due to agricultural activity and combustion of fossil fuels. At the same time human land use has directly disturbed approximately half of the global land surface (Vitousek et al., 1997), dramatically altering the capacity of ecosystems to buffer or process these nutrient inputs (Seitzinger et al., 2006). These changes in land use and nutrient flux have also altered carbon budgets, stimulating plant and algal growth in estuarine and marine ecosystems and accelerating organic matter decomposition in inland waters (Gruber and Galloway, 2008; Rosemond et al., 2015). Consequently, nitrogen and phosphorus pollution is considered to be one of the most urgent 
environmental issues currently facing humanity along with loss of biodiversity (Rockström et al., 2009).

The capacity of a watershed to remove or retain nutrients is a function of biotic and abiotic conditions encountered as water flows through the soil, groundwater, riparian zone, hyporheic zone, and stream channel itself (Brookshire et al., 2009; Seitzinger et al., 2006; Sébilo et al., 2013; Pinay et al., 2015). For catchments larger than $100 \mathrm{~km}^{2}$, riverine nutrient fluxes are tightly associated with percentage of agricultural cover (Jordan et al., 1997; Omernik et al., 1981; Strayer et al., 2003). However, in drainage basins smaller than $10 \mathrm{~km}^{2}$, nutrient fluxes vary widely despite similar land cover (Brookshire et al., 2009; Burt and Pinay, 2005; Lefebvre et al., 2007; Groffman et al., 2006; Sebilo, et al. 2013). This breakdown in the relationship between land cover and nutrient flux represents an important ecological uncertainty since $90 \%$ of global stream length occurs in catchments smaller than $15 \mathrm{~km}^{2}$ (Bishop et al., 2008). It also highlights a practical problem because although most water quality monitoring takes place in large rivers, most land-management decisions are made on the parcel or small-catchment scale (Thenail et al., 2009). The diversity in headwater-catchment response to nutrient loading also represents an opportunity to identify the mechanistic controls regulating nutrient processing and removal.

Two non-exclusive mechanisms may account for the change in variability of nutrient fluxes along stream networks. First, in-stream biogeochemical processes such as nutrient uptake and spiraling vary longitudinally in stream ecosystems, typically decreasing in importance as stream order or discharge increases (Ensign et al., 2006; Alexander et al., 2009; Hall et al., 2013). Active in-stream removal or retention of nutrients in headwaters could decouple land use from nutrient flux. Second, catchment characteristics such as topography, stream network density, and surficial geology vary moving from uplands to lowlands (Brookshire et al., 2007; Sidle, 2006; Strayer et al., 2003; Pinay et al., 2015), potentially altering terrestrial-aquatic linkages, modulating transport and processing of carbon and nutrients. To identify controls on carbon and nutrient dynamics in headwater catchments, we used a multiannual, high-frequency data set of water chemistry from three contrasting catchments in western France. Based on observations of variability in headwater catchments (Burt and Pinay, 2005), we hypothesized that landscape characteristics such as topography, surficial geology, and location within a stream network would modulate the impact of land use on water quality. We hypothesized that carbon and nutrient concentrations would show contrasting responses due to distinct sources and flow paths across scales. We expected phosphate $\left(\mathrm{PO}_{4}^{3-}\right)$ and ammonium $\left(\mathrm{NH}_{4}^{+}\right)$to be associated with surface flow, dissolved organic carbon (DOC) with surface and subsurface flow, nitrate $\left(\mathrm{NO}_{3}^{-}\right)$to come primarily from the unsaturated zone and groundwater, and dissolved silica (DSi) to come from groundwater. To test these hypotheses, we investigated both high-frequency changes in solute concentration during discharge events and overall catchment water quality.

\section{Methods}

\subsection{Study area}

We tested our hypotheses with a 5-year data set of water chemistry from three small catchments located in the Zone Atelier Armorique long-term socio-ecological research (LTSER) area in Brittany, France (Fig. 1). The research area is located on the French Massif Armoricain $\left(48^{\circ} 36^{\prime} \mathrm{N}\right.$, $1^{\circ} 32^{\prime} \mathrm{W}$ ) and is underlain by granite to the south and Brioverian schist to the north (Fig. 1c). Twenty years of meteorological data were used to estimate mean temperature and cumulative annual precipitation (Fig. S1 in the Supplement). The climate is maritime with the average monthly temperature ranging from 17.5 in July to $5^{\circ} \mathrm{C}$ in December and mean annual precipitation of $965 \mathrm{~mm}$, a third of which occurs from October to December (Fig. S1). Since the 1950s, the area has been subject to intense agriculture, with $90 \%$ of arable land used for by corn and wheat and as pastureland. The study area straddles the Couesnon and Le Guyoult River basins, which discharge into the bay of Mont-Saint-Michel and the bay of Le-Vivier-sur-Mer, respectively.

\subsection{Catchment characteristics and experimental design}

To compare the influence of catchment characteristics on carbon and nutrient concentrations we monitored water chemistry at three headwater catchments ranging from 2.3 to $10.8 \mathrm{~km}^{2}$, with distinct topography, geology, soil characteristics, and land use (Fig. 1; Table 1). For the purposes of this study we named catchments by near-surface geology, with the catchment G-01 occurring on granite, catchment S-01 occurring on schist, and catchment GS-01 straddling the boundary between the two geologies (detailed catchment characteristics presented in Fig. 1, Table 1, and Tables S1 and S2 in the Supplement). Soil depth, elevation, and land use vary systematically between the surficial geologies, with the granite portion characterized by thicker soils $(\geq 0.8 \mathrm{~m})$, higher elevation ( 85 to $110 \mathrm{~m}$ ), loamy sand soil type, and more permanent or semipermanent pastureland (Table 1 and Fig. 1). The portion of the research area underlain by schist has shallower soils $(0.45$ to $0.7 \mathrm{~m})$, a thinner weathered layer, lower elevation ( 14.5 to $60 \mathrm{~m})$, loamy soils, and a larger proportion of arable land used for corn and wheat cultivation (Fig. If and Table 1). The catchment situated in the transition zone between granite and schist (catchment GS-01) has contrasting topography (from $105 \mathrm{~m}$ upstream to $12.5 \mathrm{~m}$ at the outlet) and a mix of pasture and cultivated land.

We measured water flow and chemistry over 5 hydrologic years (from 10 April 1996 to 20 August 2000) at the outlets of the S-01 and GS-01 catchments with an au- 

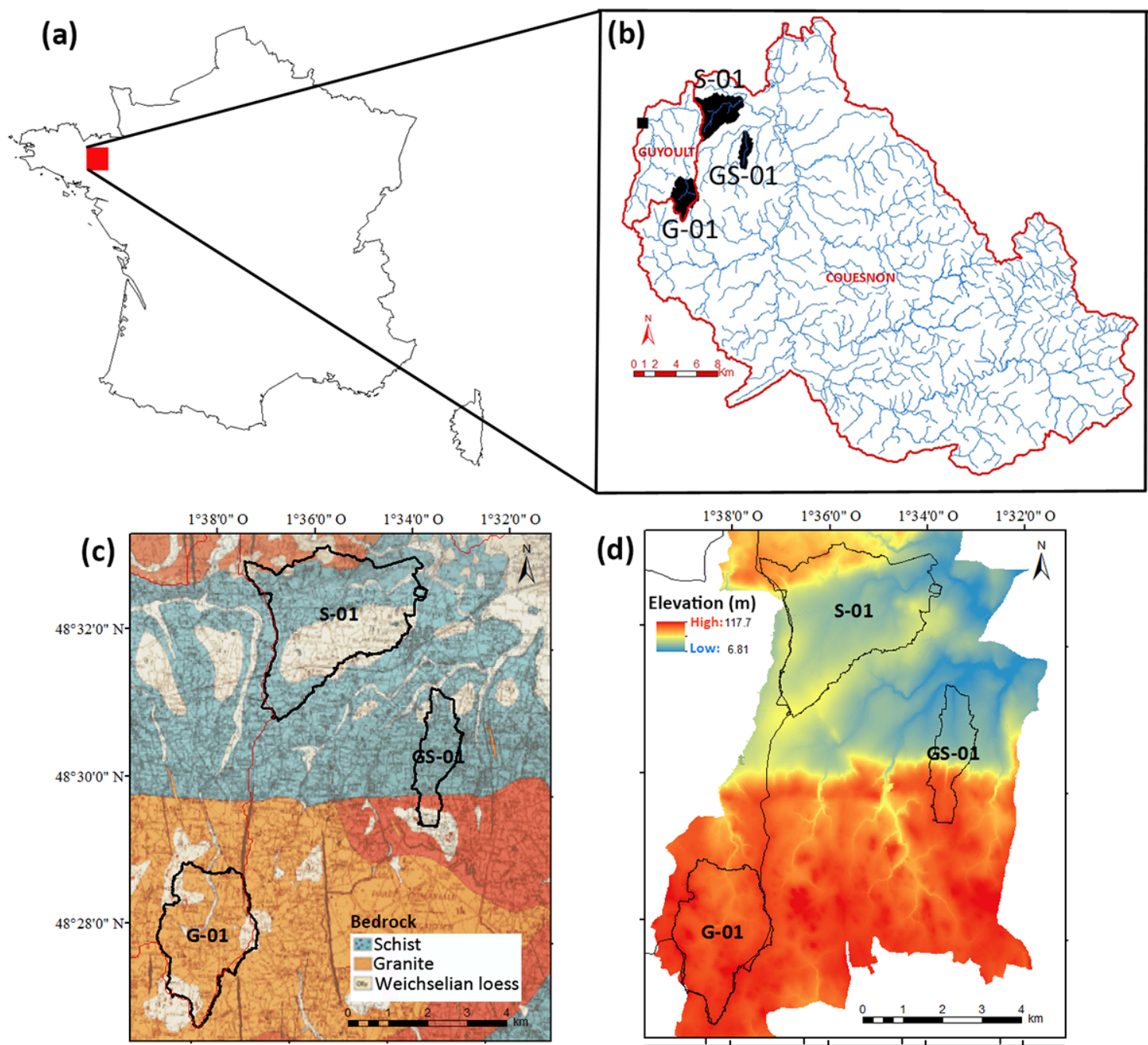

(e)

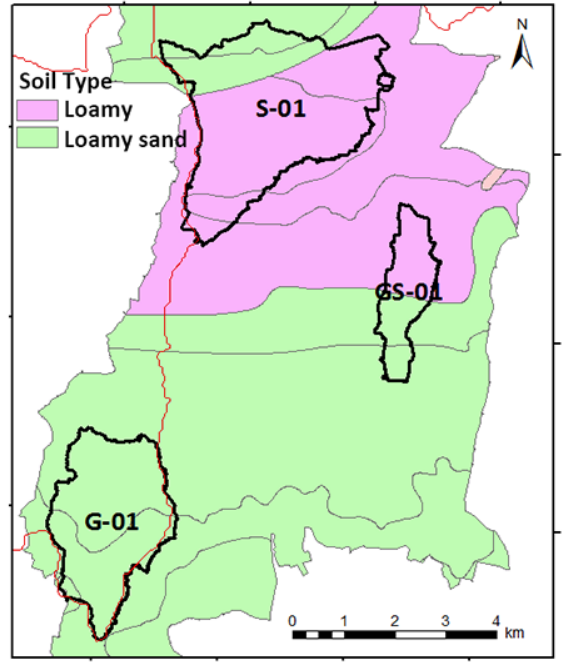

(d)

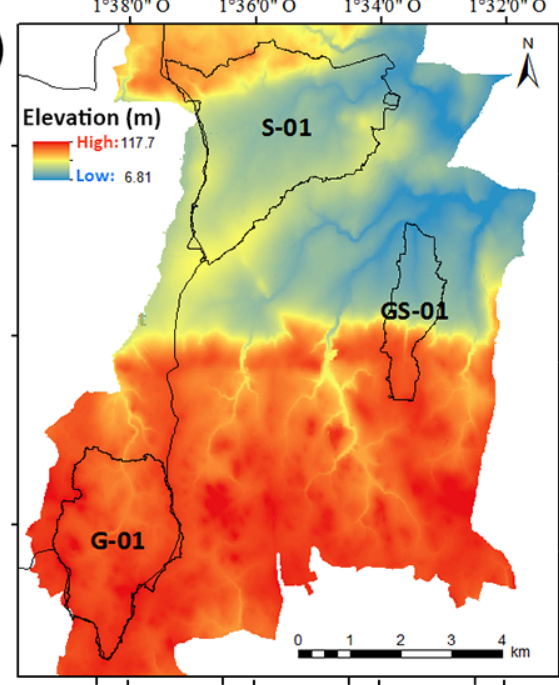

(f)

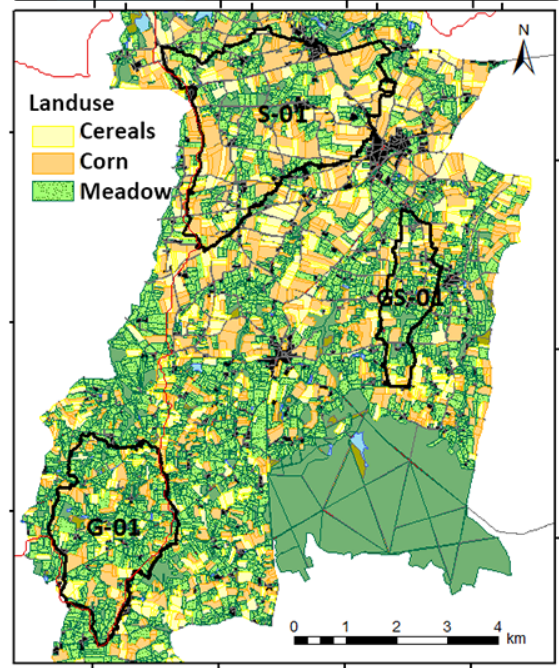

Figure 1. Location and physical characteristics of the three study catchments. Panel (a): the red square delineates the Zone Atelier Armorique LTER on the map of France. Panel (b): the catchment G-01 is a subcatchment of the Le Guyoult basin (gauged outlet indicated by black square). The two catchments GS-01 and S-01 are subcatchments of the Couesnon basin. Panel (c): geological overview showing granite in the south and schist in the north. Panel (d): digital elevation model from lidar with a $2 \mathrm{~m}$ resolution; elevation given in m.a.s.l. Panel (e): land use from the last year of study period (i.e., 2000). Panel (f): map of soil type. 
Table 1. Catchment characteristics for the catchments on granite (G-01), schist (S-01), and mixed (GS-01) substrate. Mean (standard deviation) of the percentage of corn, cereals, meadows, and woods on arable land use were determined from annual aerial photographs taken during the 5-year study period.

\begin{tabular}{lllll}
\hline & & \multicolumn{3}{c}{ Catchment } \\
\cline { 3 - 5 } & & G-01 & GS-01 & S-01 \\
\hline Soil & Depth (m) & $\geq 0.8$ & $0.7-0.8$ & $0.45-0.7$ \\
\hline Topography & Upstream elevation $(\mathrm{m})$ & 110.0 & 105.0 & 60.0 \\
& Downstream elevation $(\mathrm{m})$ & 85.0 & 12.5 & 14.5 \\
& Difference in elevation $(\mathrm{m})$ & 25.0 & 92.5 & 45.5 \\
\hline \multirow{2}{*}{ Bedrock } & Granite $(\%$ of area) & 100.0 & 17.0 & 6.0 \\
& Schist $(\%$ of area) & 0.0 & 83.0 & 94.0 \\
\hline \multirow{2}{*}{ Hydrology } & Drainage area (km $\left.{ }^{2}\right)$ & 6.4 & 2.3 & 10.8 \\
& Basin & Le Guyoult & & Couesnon \\
\hline use & $\%$ corn & $21.3(3.2)$ & $26.4(1.4)$ & $32.8(6.6)$ \\
& $\%$ wheat & $11.5(2.0)$ & $11.5(3.5)$ & $23.0(5.1)$ \\
& $\%$ pasture or forest & $65.9(6.8)$ & $61.5(11.5)$ & $41.8(4.6)$ \\
& Hedgerow density $\left(\mathrm{m} \mathrm{ha}^{-1}\right)$ & 104.72 & 82.76 & 49.77 \\
\hline
\end{tabular}

tomated sampler (Isco $3700^{\mathrm{TM}}$ ) controlled by a data logger (Campbell Scientific CR10 ${ }^{\mathrm{TM}}$ ). Stage was continuously monitored using pressure transducers and discharge was calculated from rating curves determined by manual gauging with an impeller flow meter and by salt dilution (Day, 1976; Hongve, 1987). Additionally discharge was determined at the gauged station situated at the outlet of the Le Guyoult basin (station J0323010) as a part of national environmental monitoring (Direction Régionale de l'Environnement, de l'Aménagement et du Logement de Bretagne, DREAL).

\subsection{Water quality analyses}

Water samples were collected every $12 \mathrm{~h}$ during baseflow for the first year, every 3 days for the following 2 years, and monthly for the last 2 years with automatic samplers. For catchments GS-01 and S-01, we programmed autosamplers to trigger more frequent sampling during discharge events, with samples taken every 30 min during the rising limb and every $3 \mathrm{~h}$ during the falling limb. High-frequency sampling was triggered when the water level $(h)$ changed more than $0.3 \mathrm{~cm}$ in $1 \mathrm{~min} . h$ was measured every minute with a moving hourly mean $\left(h_{\text {mean }}\right)$ calculated continuously. For each minute $t$, the trigger level $\mathrm{d} h_{(t)}$ was determined as

$\mathrm{d} h_{(t)}=h_{\text {mean }}-h_{(t)}$.

There were six discharge events captured by the automated samplers at GS-01 and S-01 from June 1997 to April 1998. For some of the longer events, sampling frequency slowed during the falling limb and for the largest event (April 1998) only the rising limb was sampled.

Water samples were filtered with $0.7 \mu \mathrm{m}$ effective pore size glass fiber filters and stored at $4{ }^{\circ} \mathrm{C}$ until analysis. Sam- ples were analyzed for $\mathrm{DOC}, \mathrm{NO}_{3}^{-}, \mathrm{NH}_{4}^{+}, \mathrm{PO}_{4}^{3-}$, dissolved silica (DSi), particulate phosphorus (PP), dissolved organic phosphorus (DOP), dissolved organic nitrogen (DON), and chloride $\left(\mathrm{Cl}^{-}\right)$. DOC was analyzed with a Shimadzu total organic carbon (TOC) analyzer and nutrients were analyzed on a Lachat Quick Chem autoanalyzer. $\mathrm{NO}_{3}^{-}$was quantified with the modified Griess-Ilosvay method with copperized cadmium reduction, $\mathrm{NH}_{4}^{+}$was quantified by indophenol blue method, $\mathrm{PO}_{4}^{3-}$ by automatic ascorbic acid method, DSi by molybdosilicate colorimetric method, and $\mathrm{Cl}^{-}$by colorimetric N-diethyl-p-phenylenediamine method. Total suspended sediment (TSS) was determined by filtering $1 \mathrm{~L}$ to $0.7 \mu \mathrm{m}$ and weighing the filter.

\subsection{Spatial data and statistical analysis}

A $2 \mathrm{~m}$ digital elevation model (DEM) based on airborne lidar data was used to extract morphological data used in the statistical analysis (Fig. 1d). We characterized surface roughness, a predictor of catchment transient storage and runoff response (Kirkby et al., 2002; Candela et al., 2005), with the mean, maximum, and minimum elevations for a grid of $10 \times 10 \mathrm{~m}$. The roughness index was calculated as

$R=\frac{\text { Mean }_{\mathrm{DEM}}-\text { Min }_{\mathrm{DEM}}}{\operatorname{Max}_{\mathrm{DEM}}-\operatorname{Min}_{\mathrm{DEM}}}, \quad 0<R<1$.

Land use was mapped annually from aerial imagery from 1996-2000, with ground validation. Forest and pastureland were distinguished from cultivated land, and corn was distinguished from other cereal crops (predominantly wheat) based on color and timing of planting and harvest. Total agricultural coverage was calculated as the sum of all corn, wheat, and other crops. The Web Map Service (WMS) of the Bureau de 
Table 2. Spearman's rank correlations for water chemistry parameters. Significant correlations $(p<0.05$, Bonferroni-corrected) are in bold.

\begin{tabular}{|c|c|c|c|c|c|c|}
\hline Catchment G-01 & Q & $\mathrm{NO}_{3}^{-}$ & $\mathrm{NH}_{4}^{+}$ & $\mathrm{PO}_{4}^{3-}$ & $\mathrm{DSi}$ & DOC \\
\hline $\mathrm{NO}_{3}^{-}$ & -0.06 & & & & & \\
\hline $\mathrm{NH}_{4}^{+}$ & 0.14 & -0.08 & & & & \\
\hline $\mathrm{PO}_{4}^{3-}$ & -0.1 & -0.09 & 0.1 & & & \\
\hline $\mathrm{DSi}^{4}$ & -0.11 & 0.23 & 0.18 & 0.28 & & \\
\hline DOC & 0.1 & -0.33 & -0.12 & 0.48 & 0.14 & \\
\hline TSS & -0.04 & -0.16 & -0.01 & 0.37 & 0.22 & 0.46 \\
\hline Catchment GS-01 & Q & $\mathrm{NO}_{3}^{-}$ & $\mathrm{NH}_{4}^{+}$ & $\mathrm{PO}_{4}^{3-}$ & $\mathrm{DSi}$ & DOC \\
\hline $\mathrm{NO}_{3}$ & -0.24 & & & & & \\
\hline $\mathrm{NH}_{4}$ & -0.1 & 0.01 & & & & \\
\hline $\mathrm{PO}_{4}$ & 0.18 & -0.30 & 0.1 & & & \\
\hline DSi & -0.08 & -0.13 & 0.04 & 0.05 & & \\
\hline DOC & 0.49 & -0.62 & 0.02 & 0.62 & 0.13 & \\
\hline TSS & 0.23 & -0.08 & 0.12 & 0.59 & -0.16 & 0.42 \\
\hline Catchment S-01 & Q & $\mathrm{NO}_{3}^{-}$ & $\mathrm{NH}_{4}^{+}$ & $\mathrm{PO}_{4}^{3-}$ & $\mathrm{DSi}$ & DOC \\
\hline $\mathrm{NO}_{3}$ & -0.14 & & & & & \\
\hline $\mathrm{NH}_{4}$ & -0.07 & -0.16 & & & & \\
\hline $\mathrm{PO}_{4}$ & -0.48 & -0.31 & 0.23 & & & \\
\hline $\mathrm{DSi}^{\top}$ & -0.16 & -0.11 & 0.25 & 0.43 & & \\
\hline DOC & 0.51 & -0.28 & 0.28 & 0.22 & 0.31 & \\
\hline TSS & 0.22 & -0.17 & 0.13 & 0.18 & 0.23 & 0.48 \\
\hline
\end{tabular}

Recherches Géologiques et Minières (BRGM) was used for the geological map of the study area.

We performed a principle components analysis (PCA) to characterize correlations in the data and identify major sources of variability in water chemistry. We included morphological parameters (geology, topography, soil depth, density of hedgerows), land use, and solute concentrations. Specifically we included bedrock (\% granite and schist), land use (wheat, corn, and pastureland), stream order (Strahler, 1952), drainage area, difference in elevation between upstream and downstream $(\mathrm{d} Z)$, and concentrations of DOC, $\mathrm{NO}_{3}^{-}, \mathrm{PO}_{4}^{3-}, \mathrm{Cl}^{-}$, and DSi. We also performed Spearman's rank correlations to test for individual correlations between water chemistry parameters. All analyses were performed in R 3.0.2 (R Core Team, 2014) with the FactoMineR package for PCA (Lê et al., 2008).

\section{Results}

\subsection{Hydrological and land-use analysis}

Hydrologic conditions varied widely across the 5 years (Table S1). The first 3 hydrological years (1 September 1995 to 31 August 1998) were 145 to $180 \mathrm{~mm}$ below the 20-year average of $965 \mathrm{~mm}$, while the last 2 years were 170 and $330 \mathrm{~mm}$ above average (Table S1, Fig. S1). Discharge from the three catchments was in good agreement with the Le Guyoult basin station though there were occasional phase shifts and departures, likely due to localized precipitation and differences in transient storage (Figs. S2, S3, S4, and S5).

The distribution of agricultural land was associated with soil and topographical parameters with $55 \%$ agricultural coverage of the total land surface in catchment S-01 in the northwest part of the study area, which has flat topography and thin soils overlying schist bedrock. Conversely, catchments G-01 and GS-01 were dominated by pastureland and forest, with less than $38 \%$ agricultural coverage (Fig. 1b, Table 1). The density of hedgerows also varied by a factor of 2 between catchments, with $105 \mathrm{~m} \mathrm{ha}^{-1}$ of hedgerows in catchment G-01 and $50 \mathrm{~m} \mathrm{ha}^{-1}$ in catchment S-01. Though there was some rotation of individual parcels between corn, wheat, and pastureland, catchment-level land use changed little over the study period, with consistent differences between the 3 catchments. For the catchment S-01, variability in land use was highest for corn and wheat (SD 6.6 and 5\%, respectively, Table 1).

\subsection{Effects of catchment characteristics on water chemistry}

The relationship between specific discharge and solute concentration differed by solute and catchment (Figs. 2, 3, S7, and S8). Solutes typically expressed one of three responses to increases in discharge: an asymptotic increase (TSS, DOC), an asymptotic decrease (DON, DOP, and $\mathrm{PO}_{4}^{3-}$ ), or a de- 


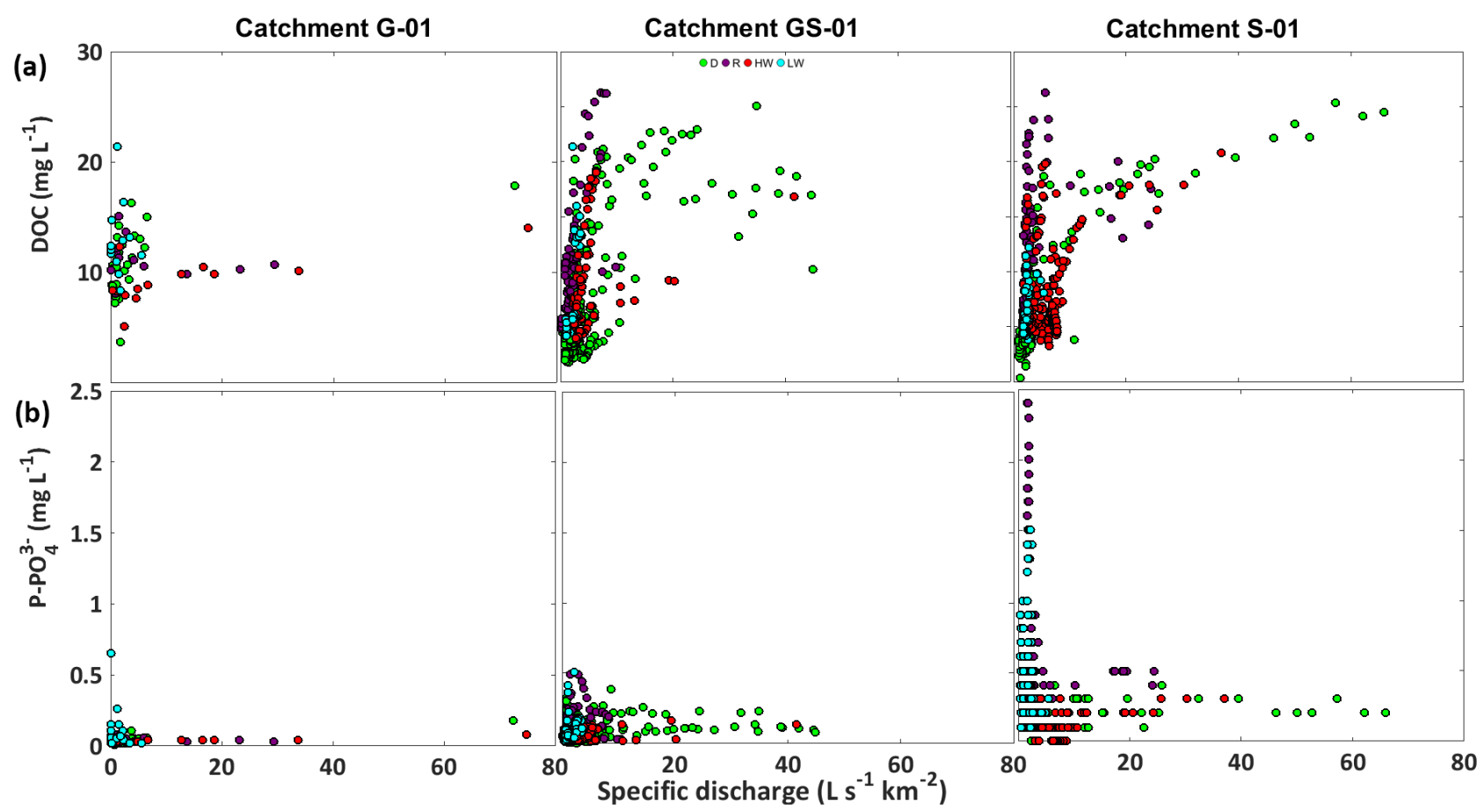

Figure 2. Relationship between specific discharge and (a) dissolved organic carbon, on the one hand, and (b) phosphate, on the other hand, for three headwater catchments (G-01, GS-01, and S-01) in Brittany, France. Chemistry data from daily automatic sampling supplemented by sub-daily sampling for catchments GS-01 and S-01 during discharge events (see methods for detailed sampling description). Data are colored by hydrologic period: D - discharge (April-June); LW - low water (July-September); R - recharge (October-December); HW high water (January-March).

crease in variability and a convergence to a moderate concentration $\left(\mathrm{NO}_{3}^{-}, \mathrm{NH}_{4}^{+}, \mathrm{DSi}\right.$, and $\left.\mathrm{Cl}^{-}\right)$. Solutes with similar response patterns were more tightly correlated, though significance and sometimes the sign of individual relationships varied somewhat by catchment (Table 2). The catchment G-01, which had a low gradient, high roughness, and relatively less agriculture, had more stable chemistry during both baseflow and high-flow conditions, particularly for DOC, TSS, $\mathrm{Cl}^{-}, \mathrm{NO}_{3}^{-}$, and all phosphorus species (Figs. 2, 3 , S7, and S8). This lower amplitude of variation in water chemistry in catchment G-01 resulted in fewer significant correlations between water chemistry parameters, and notably discharge was not significantly correlated with any solute concentrations ( $p>0.05$, Spearman's rank correlation; Table 2). The steep and small catchment GS-01 and the highly agricultural catchment S-01 showed similar patterns of solute response to discharge, though nitrogen and phosphorus concentrations were generally lower in GS-01 than S-01 (Figs. 3 and S8). GS-01 had lower maximum specific discharge $\left(47 \mathrm{~L} \mathrm{~s}^{-1} \mathrm{~km}^{-2}\right)$ than catchment S$01\left(66 \mathrm{~L} \mathrm{~s}^{-1} \mathrm{~km}^{-2}\right.$; Figs. 2 and 3$)$.

Mean DOC concentration was highest in catchment G-01 but did not differ between catchments GS-01 and S, despite a $20 \%$ difference in agricultural coverage (Table 1). Mean $\mathrm{NO}_{3}^{-}$concentration increased linearly with agricultural cov- erage from an average of $5 \mathrm{mg} \mathrm{N} \mathrm{L}^{-1}$ in G-01 to an average of $10 \mathrm{mg} \mathrm{N} \mathrm{L}^{-1}$ in S-01 (Fig. S9). The highest concentration and variability in $\mathrm{PO}_{4}^{3-}$ occurred in $\mathrm{S}-01$, where mean $\mathrm{PO}_{4}^{3-}$ concentration was nearly 3 times higher than in the less agricultural catchments (Fig. S9).

The PCA exploring the structure of the water chemistry data and catchment characteristics explained $80 \%$ of the variability in the data with the first three axes (Figs. 4 and S6). The first axis explained $50 \%$ of the overall variability and was most strongly correlated with hedgerow density $(r=0.98)$, land use $(r=-0.94,0.92$, and 0.78 for meadows, corn, and wheat, respectively), geology $(r=-0.70$ for percent of catchment underlain by granite), and $\mathrm{NO}_{3}^{-}$ $(r=0.66)$. The second axis explained $19 \%$ of total variability and was positively associated with DOC $(r=0.88)$ and discharge $\left(R^{2}=0.69\right)$ and negatively associated with $\mathrm{NO}_{3}^{-}$ $\left(R^{2}=-0.46\right)$. The third axis explained $10 \%$ of total variability and was associated primarily with $\mathrm{PO}_{4}^{3-}\left(R^{2}=0.79\right)$. Overall, the first axis was determined by physical context (geology and topography represented by the differences in elevation and land use) and the second axis was determined by factors strongly associated with hydrology (discharge, TSS, and DOC). The three catchments showed clear separation along the first axis and varied along the second axis largely within their discrete, first-dimensional boundaries. 
The main departures along axis three (in the upper right corner of Fig. 4) are from $\mathrm{PO}_{4}^{3-}$ flushing events during dry years (year 1 and year 3 ).

\subsection{Solute dynamics during discharge events}

The high-frequency samples collected during six discharge events at S-01 and GS-01 revealed a primarily counterclockwise hysteresis for DOC (higher concentration during the falling limb than at the equivalent discharge on the rising limb), a clockwise hysteresis for $\mathrm{NO}_{3}^{-}$and $\mathrm{PO}_{4}^{3-}$, and no clear pattern in $\mathrm{NH}_{4}^{+}$except for large variations during the rising limb of the discharge events (Fig. S10). DOC and $\mathrm{NO}_{3}^{-}$concentrations during discharge events were strongly negatively correlated (Figs. S11 and S12), with the elements showing nearly mirror-image responses to changes in discharge. $\mathrm{NO}_{3}^{-}$concentration was highest and DOC was lowest at or immediately after the start of the discharge event, except for GS-01 during the largest two discharge events that were sampled in April 1998 when $\mathrm{NO}_{3}^{-}$was higher and DOC was lower after the event (Figs. S9, S10). DOC concentration was higher during the second storm pulse than the first for that compound event. Maximum $\mathrm{PO}_{4}^{3-}$ concentration typically occurred after the $\mathrm{NO}_{3}^{-}$peak but before the maximum discharge, except for S-01 in November 1997. Maximum ammonium concentration occurred during the rising limb. DOC was more strongly correlated with discharge for S-01, though DOC increased for both catchments during the rising limb of the hydrograph (Fig. S10). $\mathrm{PO}_{4}^{3-}$ concentration increased strongly at both sites at the onset of the rising limb, with similar peaks for the two subsequent discharge events in S-01 (Fig. S10).

\subsection{Interannual solute dynamics}

The three catchments showed distinct interannual dynamics for both hydrology and solute concentrations across the contrasting hydrologic years (Fig. 5). Specific discharge was consistently lowest for catchment GS-01, the steep transition catchment (Fig. 5a). DOC concentration in G-01 was invariant across the dry and wet years, whereas annual median DOC in GS-01 and S-01 generally tracked discharge (Fig. 5b). Highest median DOC concentration occurred in year 3 for all catchments, which was the year of transition from dry to wet conditions and the year with the most highflow events. Contrary to the high-frequency trends, annual $\mathrm{NO}_{3}^{-}$was positively associated with annual discharge for GS-01 and S-01 (Fig. 5c). Catchment G-01 was again relatively distinct in its behavior, with stable $\mathrm{NO}_{3}^{-}$concentrations across years (Fig. 5d). Annual $\mathrm{PO}_{4}^{3-}$ concentration was negatively correlated with annual discharge across sites, with significantly higher concentrations in dry years (Fig. 5e). DSi was similar for catchments G-01 and S-01 but was consistently elevated for the steep catchment GS-01 (Fig. 5f).

\section{Discussion}

To quantify the influence of physical, hydrologic, and anthropogenic controls on surface water quality, we monitored discharge and water chemistry from three agricultural catchments in western France for 5 years. We hypothesized that carbon and nutrient concentrations would show contrasting responses to topographic and land-use differences due to both distinct sources and transport dynamics across scales. We found that carbon and nutrient dynamics differed between the three study catchments both on event and interannual temporal scales. However, spatially, the effect of hydrology on solute concentration was strongly modulated by catchment characteristics such as hedgerow density, agricultural activity, and geology. Because the distribution of agricultural activity in these catchments is largely a consequence of the geologic and topographic context, these factors are the ultimate controls on the retention and release of carbon and nutrients, potentially explaining the decoupling of agricultural activity and water quality observed in small catchments (Burt and Pinay, 2005).

\subsection{Proximate and ultimate controls on water quality}

The relationship between agricultural practice and hydrologic nutrient flux is strong on the large-basin scale but breaks down on the small-basin scale, with widely different water chemistry in catchments with similar land covers (Brookshire et al., 2009; Burt and Pinay, 2005; Lefebvre et al., 2007). In our study, this phenomenon is apparent for catchments G-01 and GS-01, which have very similar land use but distinct carbon and nutrient signatures, and for catchments GS-01 and S-01, which have distinct land use but similar chemical dynamics (Table 2). These differences in carbon and nutrient dynamics can be attributed to catchment characteristics, which modulate the effect of land use on carbon and nutrient dynamics. Granite parent material, such as in G-01, can give rise to thick but relatively acidic soils compared to schist substrate which produces thin and rich soils more conducive to row crop cultivation. Thicker soil and higher surface roughness in catchment G-01 (Fig. S13) increase transient storage and residence time (Kolbe et al., 2016), buffering the catchment to fluctuations in water chemistry. This is reflected in relatively invariant carbon and nutrient chemistry across hydrologic conditions. Conversely, catchments GS-01 and S-01, which are underlain primarily by schist, respond to both short- and long-term hydrologic changes with high concentrations of $\mathrm{PO}_{4}^{3-}$ and $\mathrm{NH}_{4}^{+}$during low flow conditions and strong increases in DOC, sediment, and particulate organic matter during high flows. This pattern held on interannual timescales as well, where the catchment on granitic substrate showed remarkable stability, while for the predominantly schist catchments, DOC concentration decreased with discharge in the wettest years. 


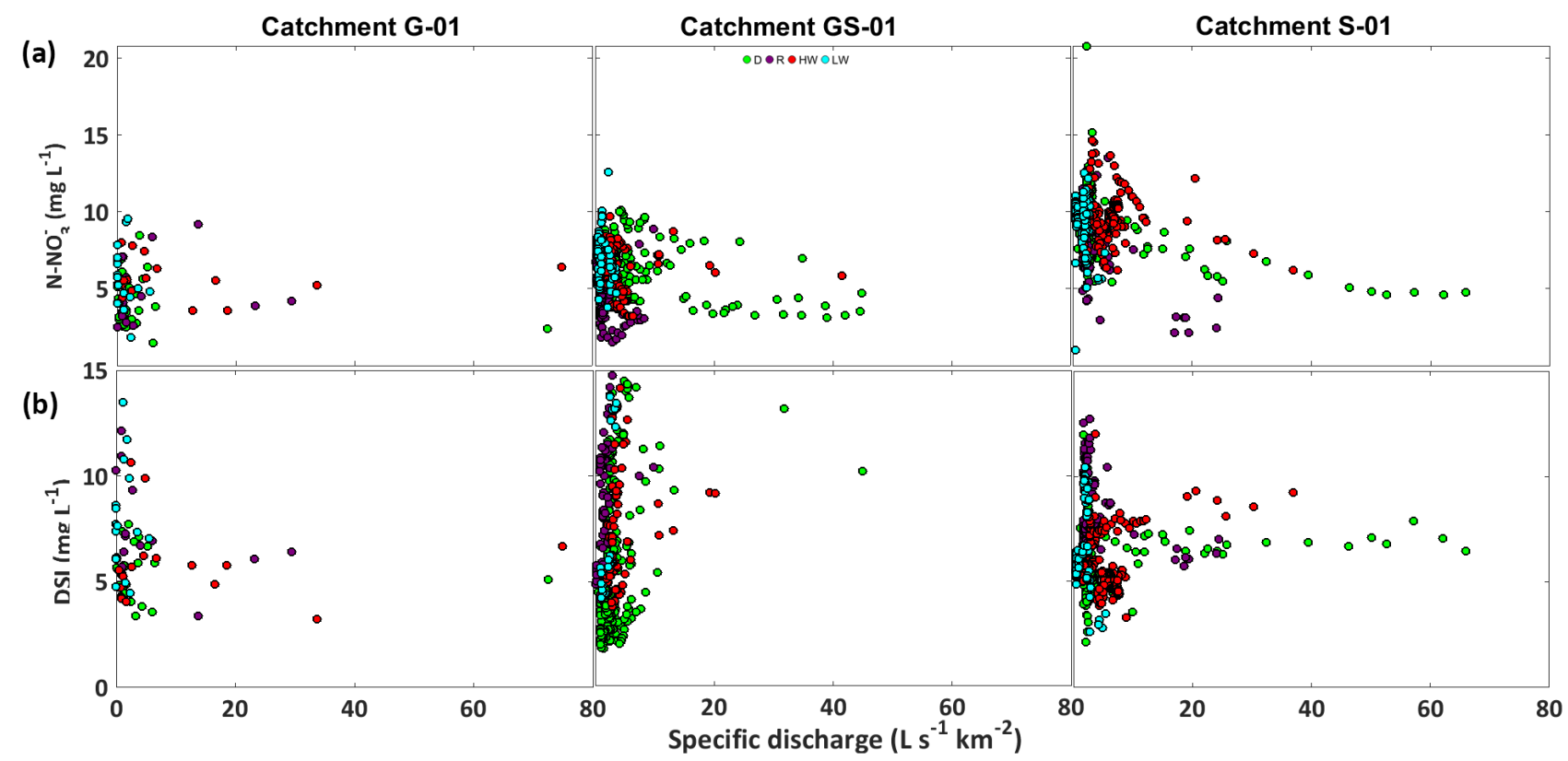

Figure 3. Relationship between specific discharge and (a) nitrate, on the other hand, and (b) dissolved silica, on the other hand, for three headwater catchments (G-01, GS-01, and S-01) in Brittany France. Chemistry data from daily automatic sampling supplemented by sub-daily sampling for catchments GS-01 and S-01 during discharge events (see "Methods" section for detailed sampling description). Data points are colored by hydrologic period (see Fig. 2 for definitions).

In addition to directly influencing catchment hydrology and nutrient retention, geology and accompanying topographic and geomorphological factors exert a strong control on the distribution of human agriculture, indirectly influencing nutrient loading and disturbance regime. Because farmers and land managers do not randomly select surfaces for cultivation, land use in Brittany and throughout the world closely follows geologic and soil characteristics. Soil fertility is a function of natural weathering processes and land use (Tye et al., 2013). Spatial variability of soil moisture, which is often controlled by topography and soil properties (Yeakley et al., 1998), plays important roles in land-use distribution and organization. In our study area, the interactions between catchment context and human use have resulted in preferential agricultural development of schist catchments, which unfortunately appear to be more prone to nutrient export.

In other contexts, this interaction between the risk of human development and resilience to human disturbance can also mitigate impacts of agriculture (e.g. through the preservation of forest in steep, erodible environments; Odgaard et al., 2013), but whether it has a net increase or decrease in human impacts on aquatic ecosystems on a global scale is largely unknown (Zabel et al., 2014; Ramankutty et al., 2008). We hypothesize that the preferential development of certain surfaces would decrease in areas of intense anthropogenic pressure where selectivity decreases as the system reaches saturation (Li et al., 2014) but could strongly influence the distribution of human activity in systems that are expanding or contracting such as the developing world or areas of rural exodus such as much of France. Quantifying the regional effects of the selective development of more or less resilient surfaces would be possible with existing data by intersecting water chemistry data sets with soil and geologic geographic information. This framework would provide guidance on multiple scales for land managers seeking to improve water quality while continuing agricultural production.

\subsection{Controls on chemistry across scales}

We present a synthesis of our understanding of carbon and nutrient dynamics in different catchment components in Fig. 6. Based on discharge deconvolution, the connectivity between unsaturated and saturated zones depends on water input to the soil and weathered zone. Organic carbon is consumed by microorganisms and phosphorus is sorbed to soil particles as water moves downward. Conversely, the relative abundance of inorganic nitrogen (particularly $\mathrm{NO}_{3}^{-}$) increases due to mineralization and nitrification, shifting the nutrient stoichiometry. Consequently, nutrient concentration in streams depends on the connectivity and thickness of those layers, which determine stoichiometry, and typical water velocity, which determines solute flux. By modulating the connectivity between the hydrologic compartments, discharge regime controls nutrient export (DOC and $\mathrm{PO}_{4}^{3-}$ increasing with discharge and $\mathrm{NO}_{3}^{-}$decreasing). On shorter timescales, sinusoidal nutrient fluctuations result from discrete storm 


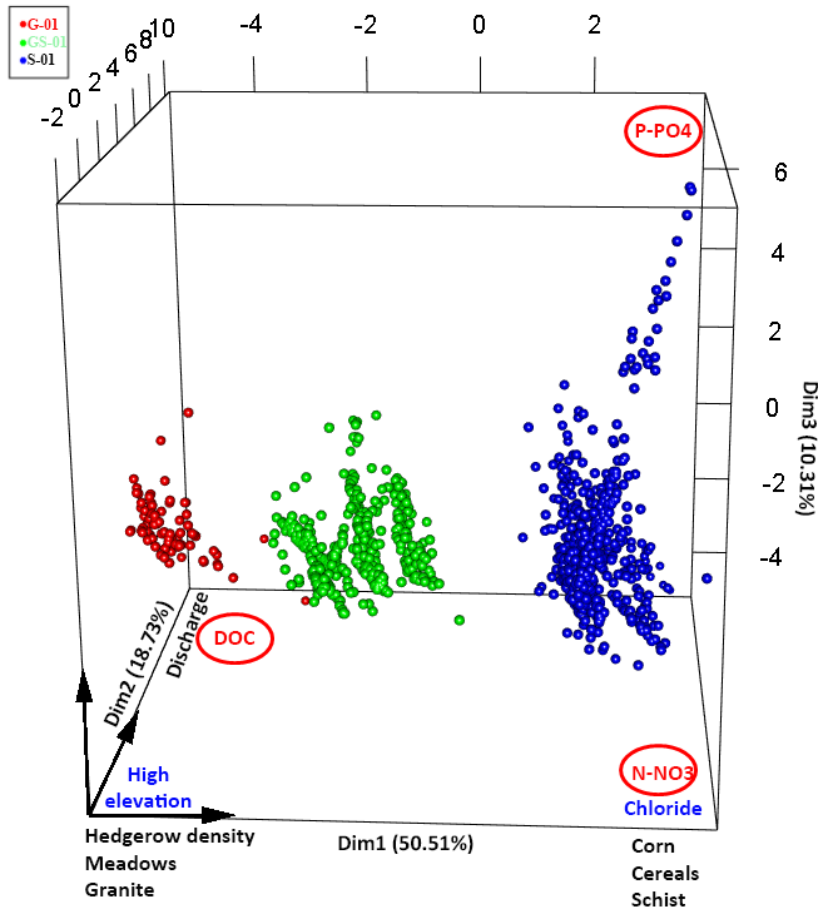

Figure 4. Principle components analysis of the major sources of variability in water chemistry. Together, the first three axes explain $80 \%$ of the total variability of the data. Principal and supplementary variables are indicated respectively in black and blue. Red circles indicate the poles of carbon, nitrogen, and phosphorus associated with cereals and corn for $\mathrm{N}_{-} \mathrm{NO}_{3}^{-}$, high discharge on granite bedrock for DOC, and both discharge and agricultural land use for $\mathrm{P}_{-} \mathrm{PO}_{4}^{3-}$. PCA scores are indicated in Table S3.

events. Various pathways and interaction between hillslope and stream are affected to a lesser extent by discharge regime (Fig. 6). Groundwater fluxes toward the stream may also control nutrient concentration especially for $\mathrm{NO}_{3}^{-}$, which is relatively highest in this compartment (Fig. 6).

Different mechanisms can influence short- and long-term elemental fluxes (Meybeck and Moatar, 2012; Moatar et al., 2013), explaining the contrasting short- and long-term dynamics observed within individual catchments. For example, conditions that favor frequent flushing of soil may decrease short-term $\mathrm{NO}_{3}^{-}$concentration but result in larger overall fluxes. In our study, $\mathrm{NO}_{3}^{-}$concentration showed a nonlinear decrease with discharge on short timescales but was higher in wetter years (Fig. 5), potentially due to changing $\mathrm{NO}_{3}^{-}$ sources. The convergence of $\mathrm{NO}_{3}^{-}, \mathrm{Cl}^{-}$, and DSi concentrations across catchments during high-flow periods (Figs. 2, 3 and S7, S8) implies a shift from catchment-scale controls on water chemistry during low flows to larger inter-catchment controls during high flows. The upper layer of the Brioverian schist substrate beneath these drainage basins is composed of unconsolidated weathered substrate of variable thickness that could provide an inter-basin solute source during storms.

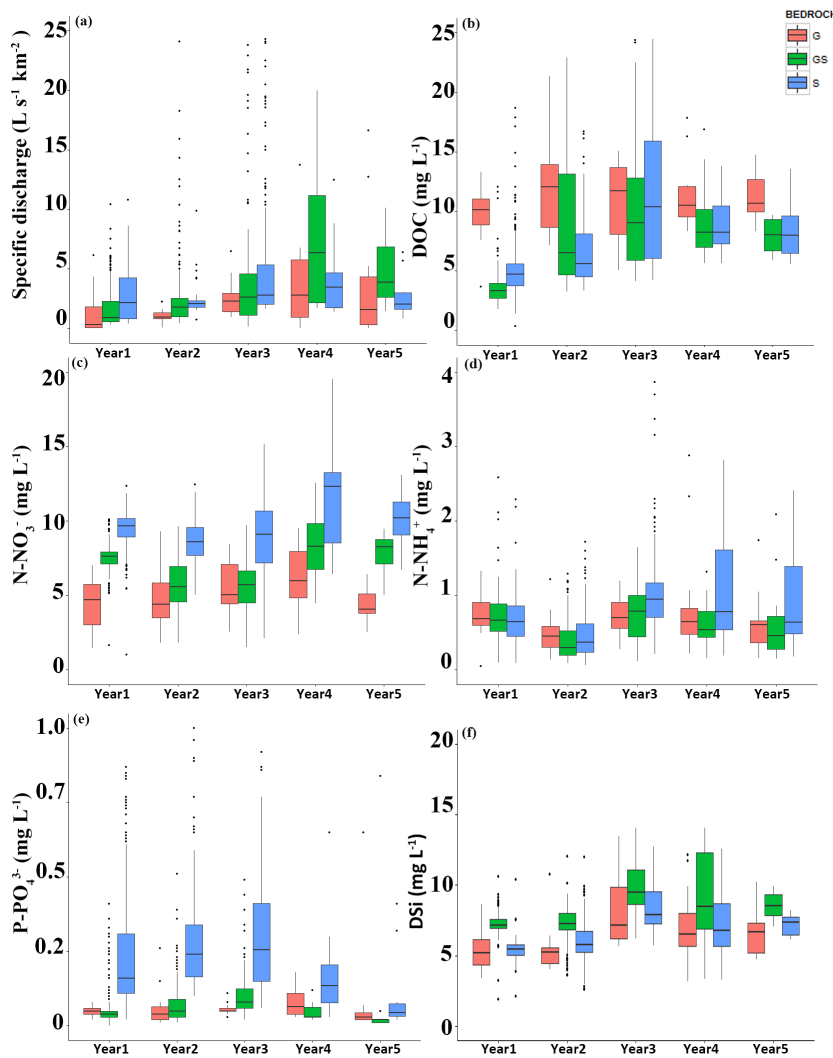

Figure 5. Discharge and carbon and nutrient concentrations during 5 contrasting hydrological years. Boxplots of (a) specific discharge, (b) dissolved organic carbon, (c) nitrate, (d) ammonium, (e) phosphate, and (f) dissolved silica for the catchments G-01 (red box), GS-01 (green box), and S-01 (blue box). Boxplots represent median, quartiles, minimum, and maximum within 1.5 times the interquartile range and outliers beyond 1.5 interquartile range.

This shallow, unconfined aquifer has $\mathrm{NO}_{3}^{-}$values that correspond to those measured at the catchment outlets during high-water periods (Clément et al., 2003) and in other regional aquifers (Molénat et al., 2008). The lack of significant dilution of $\mathrm{NO}_{3}^{-}$and $\mathrm{Cl}^{-}$during discharge events and the increase in DOC concentrations suggest that high flow is composed of both groundwater, presumably from the Brioverian schist, and shallow subsurface flow (Grimaldi et al., 2009, 2012), including through the sub-soil weathered layer (Iwagami et al., 2010). The $\mathrm{NO}_{3}^{-}$mobilized during storms may already be present or could result from mineralization and nitrification as the soils wet up. The lower, but also constant, concentration of $\mathrm{NH}_{4}^{+}$measured during high-water periods supports the hypothesis of high nitrogen mineralization from soil organic matter during these mild and humid periods and high $\mathrm{NH}_{4}^{+}$retention in soil. Nitrification of $\mathrm{NH}_{4}^{+}$to $\mathrm{NO}_{3}^{-}$during these same periods could maintain $\mathrm{NO}_{3}^{-}$supply, assuming that soils do not become waterlogged and anoxic. The relationship between $\mathrm{NO}_{3}^{-}$and $\mathrm{NH}_{4}^{+}$concentrations with discharge during a high water period (Figs. 3 and S8) follows 


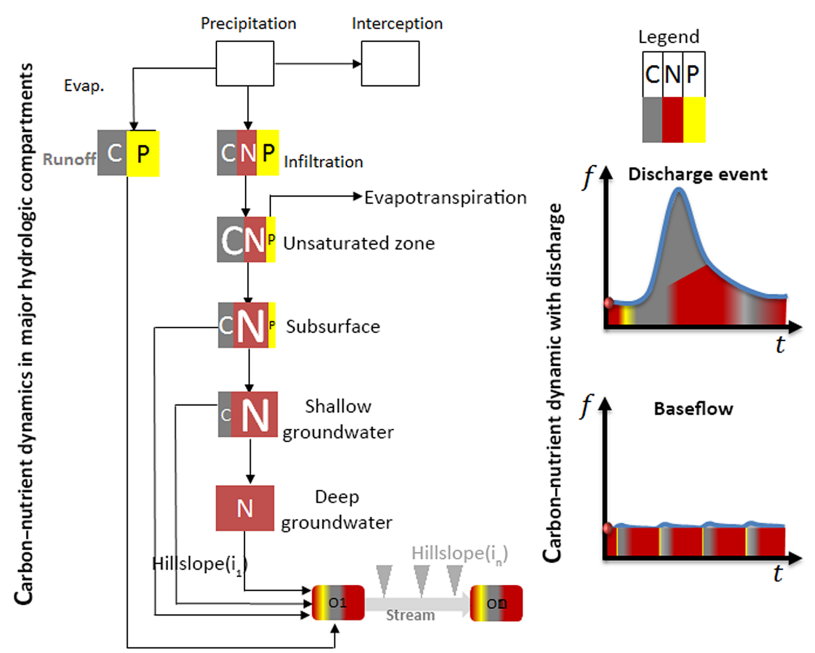

Figure 6. Conceptual model of carbon and nutrient dynamics in major hydrologic compartments during transient (discharge events) and steady-state (baseflow) discharge regimes. On the left side, we represent the relative abundance of carbon, nitrogen, and phosphate during vertical transport through soil, unsaturated zone, and groundwater. Arrows represent flow paths, which can either descend through the soil column or lead directly to the stream (represented at the bottom of the figure), which experiences fluctuations in water chemistry based on the relative contribution of these flow paths from multiple hillslopes. On the right side of the figure, schematic representations of stream chemistry during stormflow and baseflow are shown. The colors represent carbon, nitrogen, and phosphorus concentrations, which vary depending on hydrologic conditions. See Sect. 4.2 in the "Discussion" section for more detailed interpretation.

a logarithmic or linear trend, underlining the importance of soil as an active nitrogen source during high-flow periods since the $\mathrm{NH}_{4}^{+}$concentration in groundwater is low. These differences in short- and long-term dynamics highlight the importance of considering management goals when designing water quality monitoring strategies, with high-frequency monitoring during extreme flows necessary to identify peak concentrations and lower-frequency, long-term monitoring more appropriate for evaluating annual loads.

The divergent response of chemistry across temporal scales can give insight into sources and pathways of carbon and nutrients. For catchments GS-01 and S-01, DOC increased strongly with discharge on both event and interannual scales (Figs. 2 and 5). However, high concentrations of DON and DOP were only observed at low flows (Fig. S7). This shift in dissolved organic matter (DOM) stoichiometry indicates a change in DOC sources, with stormflow dominated by plant-derived DOM from surface soils and baseflow dominated by microbial DOM from deeper soils and shallow groundwater (Inamdar et al., 2012; Yang et al., 2015). The rapid increase in DOC concentration early in discharge events, followed by a plateau at high discharge, indicates source limitation of DOC, potentially due to changes in con- tributing area. In colluvial soils such as our study area, riparian wetlands are the major source of DOC to the stream, based on ${ }^{13} \mathrm{C}$ and molecular analysis of DOC (Jeanneau et al., 2014; Lambert et al., 2014). At the beginning of a storm event, this riparian DOC is readily transported to the stream, but increased discharge connects upslope soils, which tend to be poorer in organic carbon, resulting in a plateau (Follain et al., 2007; Laudon et al., 2011). High DOC concentration in these headwater agricultural streams highlights the importance of understanding carbon production and transport dynamics in small freshwater systems (Agren et al., 2007; Cole et al., 2007).

\subsection{Hedgerow density and vegetation effect on soil and shallow groundwater}

We found that the effect of hydrology on solute concentration was strongly modulated by hedgerow density, which was the strongest predictor of stream chemistry in the PCA. There was less variation in carbon and nutrient concentrations for the highest hedgerow density catchment G-01. Hedgerows exert multiple controls on hydrology and biology (Mérot and Bruneau, 1993). Because vegetation is one of the major controls on water and energy balance, the removal or redistribution of vegetation with land use alters albedo and evapotranspiration (Davin et al., 2007). Vegetation plays a central role in the interface between the atmosphere and groundwater via water uptake by roots and redistribution of water in the soil column, affecting soil moisture and groundwater recharge. Increased transpiration (Thomas et al., 2012) and interception (Ghazavi et al., 2008) by hedgerows can decrease soil moisture on a local scale, potentially reducing the transfer of carbon and nutrients from soils to groundwater or surface waters. Indeed, the relatively dry soil beneath hedgerows (Caubel et al., 2001; Thomas et al., 2008) corresponds with lower soil and groundwater $\mathrm{NO}_{3}^{-}$concentration (Grimaldi et al., 2012). Enhanced $\mathrm{NO}_{3}^{-}$removal and retention by hedgerows could be due to both increased variability in soil moisture and longer residence time, which create local microsites for denitrification (Parkin, 1987) and increase the likelihood of uptake. In our study area, hedgerow density is also associated with geologic and topographic parameters. In catchments S-01 and GS-01, where soils are more suitable for intensive agriculture, hedgerows were removed to consolidate fields during the post-war period. While our study cannot untangle the relative impacts of hedgerow density and geology, it does suggest that hedgerow density can impact $\mathrm{NO}_{3}^{-}$mass balance on larger scales.

\section{Conclusions}

Proximate and ultimate controls on carbon and nutrient concentrations differ across spatial and temporal scales, revealing distinct sources and transport dynamics for different ele- 
ments. Thicker soils and higher surface roughness for catchments underlain by granite buffer fluctuations in water chemistry on both event and interannual scales, potentially due to increased transient storage and residence time from higher roughness and hedgerow density. Conversely, nutrient concentrations in catchments on schist substrates are highly sensitive to changes in hydrology. However, the convergence of water chemistry between catchments during discharge events suggests larger, regional influences independent of geology and topography.

Direct human impact on a catchment (fertilizer input, soil disturbance, urbanization) is asymmetrically linked with inherent catchment properties (geology, soil, topography), which together determine catchment resilience or vulnerability to human activity. The effect of hydrology on solute concentration is proximately controlled by catchment characteristics such as hedgerow density and agricultural activity, but because the distribution of agricultural land use in these catchments is largely a consequence of the geologic and topographic context, these are the ultimate controls on retention and release of carbon and nutrients. This link between inherent catchment buffering capacity and probability of human disturbance provides a useful perspective for evaluating vulnerability of aquatic ecosystems and for managing systems to maintain production while minimizing leakage of nutrients.

\section{The Supplement related to this article is available online at doi:10.5194/bg-13-1863-2016-supplement.}

Author contributions. Gilles Pinay and Jacques Baudry designed the experiments. Olivier Troccaz carried them out. Zahra Thomas and Benjamin W. Abbott analyzed the data and prepared the manuscript with contributions from all coauthors.

Acknowledgements. We thank Jean Nabucet (LETG, University of Rennes 2) for the land-use maps. We also thank Pascal Pichelin and Hervé Squividant (AGROCAMPUS OUEST, UMR SAS) for maintaining and updating services and server for open access to data (http://geowww.agrocampus-ouest.fr/web/?page_id=1346) and the LTER Zone Atelier Armorique. Thanks to the BRGM for geological maps.

Edited by: R. Bol

\section{References}

Agren, A., Buffam, I., Jansson, M., and Laudon, H.: Importance of seasonality and small streams for the landscape regulation of dissolved organic carbon export, J. Geophys. Res.-Biogeo., 112, G03003, doi:29/2006jg000381, 2007.
Alexander, R. B., Böhlke, J. K., Boyer, E. W., David, M. B., Harvey, J. W., Mulholland, P. J., Seitzinger, S. P., Tobias, C. R., Tonitto, C., and Wollheim, W. M.: Dynamic modeling of nitrogen losses in river networks unravels the coupled effects of hydrological and biogeochemical processes, Biogeochemistry, 93, 91-116, doi:10.1007/s10533-008-9274-8, 2009.

Bishop, K., Buffam, I., Erlandsson, M., Fölster, J., Laudon, H., Seibert, J., and Temnerud, J.: Aqua Incognita: the unknown headwaters, Hydrol. Process., 22, 1239-1242, doi:10.1002/hyp.7049, 2008.

Brookshire, E. N. J., Valett, H. M., Thomas, S. A., and Webster, J. R.: Atmospheric $\mathrm{N}$ deposition increases organic $\mathrm{N}$ loss from temperate forests, Ecosystems, 10, 252-262, 2007.

Brookshire, E. N. J., Valett, H. M., and Gerber, S.: Maintenance of terrestrial nutrient loss signatures during in-stream transport, Ecology, 90, 293-299, doi:10.1890/08-0949.1, 2009.

Burt, T. P. and Pinay, G.: Linking hydrology and biogeochemistry in complex landscapes, Prog. Phys. Geog., 29, 297-316, doi:10.1191/0309133305pp450ra, 2005.

Candela, A., Noto, L. V., and Aronica, G.: Influence of surface roughness in hydrological response of semiarid catchments, J. Hydrol., 313, 119-131, doi:10.1016/j.jhydrol.2005.01.023, 2005.

Caubel-Forget, V., Grimaldi, C., and Rouault, F.: Contrasted dynamics of nitrate and chloride in groundwater submitted to the influence of a hedge, C. R. Acad. Sci. Paris, 332, 107-113, 2001

Clément, J., Aquilina, L., Bour, O., Plaine, K., Burt, T. P., and Pinay, G.: Hydrological flowpaths and nitrate removal rates within a riparian floodplain along a fourth-order stream in Brittany (France), Hydrol. Process., 17, 1177-1195, 2003.

Cole, J. J., Prairie, Y. T., Caraco, N. F., McDowell, W. H., Tranvik, L. J., Striegl, R. G., Duarte, C. M., Kortelainen, P., Downing, J. A., Middelburg, J. J., and Melack, J.: Plumbing the global carbon cycle: Integrating inland waters into the terrestrial carbon budget, Ecosystems, 10, 171-184, 2007.

Davin, E. L., de Noblet-Ducoudré, N., and Friedlingstein, P.: Impact of land cover change on surface climate Relevance of the radiative forci, Geophys. Res. Lett., 34, 1-5, 2007.

Elser, J. and Bennett, E.: Phosphorus cycle: A broken biogeochemical cycle, Nature, 478, 29-31, doi:10.1038/478029a, 2011.

Ensign, S. H., McMillan, S. K., Thompson, S. P., and Piehler, M. E.: Nitrogen and phosphorus attenuation within the stream network of a coastal, agricultural watershed, J. Environ. Qual., 35. 12371247, 2006.

Follain, S., Walter, C., Legout, A., Lemercier, B., and Dutin, G.: Induced effects of hedgerow networks on soil organic carbon storage within an agricultural landscape, Geoderma, 142, 80-95, 2007.

Ghazavi, G., Thomas, Z., Hamon, Y., Marie, J. C., Corson, M., and Merot, P.: Hedgerow impacts on soil-water transfer due to rainfall interception and root-water uptake, Hydrol. Process., 22, 4723-4735, doi:10.1002/hyp.7081, 2008.

Grimaldi, C., Thomas, Z., Fossey, M., Fauvel, Y., and Merot, P.: High chloride concentrations in the soil and groundwater under an oak hedge in the West of France: an indicator of evapotranspiration and water movement, Hydrol. Process., 23, 1865-1873, 2009.

Grimaldi, C., Fossey, M., Thomas, Z., Fauvel, Y., and Merot. P.: Nitrate attenuation in soil and shallow groundwater under a bottom- 
land hedgerow in a European farming landscape, Hydrol. Process., 26, 3570-3578, doi:10.1002/hyp.8441, 2012.

Groffman, P. M., Altabet, M. A., Bohlke, J. K., Butterbach-Bahl, K., David, M. B., Firestone, M. K., Giblin, A. E., Kana, T. M., Nielsen, L. P., and Voytek, M. A.: Methods for measuring denitrification: diverse approaches to a difficult problem, Ecol. Appl., 16, 2091-122, 2006.

Gruber, N. and Galloway, J. N.: An Earth-system perspective of the global nitrogen cycle, Nature, 451, 293-296, doi:10.1038/nature06592, 2008.

Hall Jr., R. O., Baker, M. A., Rosi-Marshall, E. J., Tank, J. L., and Newbold, J. D.: Solute-specific scaling of inorganic nitrogen and phosphorus uptake in streams, Biogeosciences, 10, 7323-7331, doi:10.5194/bg-10-7323-2013, 2013.

Hongve, D.: A revised procedure for discharge measurement by means of the salt dilution method, Hydrol. Process., 1, 267-270, 1987.

Inamdar, S., Finger, N., Singh, S., ; Mitchell, M., Levia, D., Bais, H., Scott, D., and McHale, P.: Dissolved organic matter (DOM) concentration and quality in a forested mid-Atlantic watershed, USA, Biogeochemistry, 108, 55-76, doi:10.1007/s10533-0119572-4, 2012.

Iwagami, S., Tsujimura, M., Onda, Y., Shimada, J., and Tanaka, T.: Role of bedrock groundwater in the rainfallrunoff process in a small headwater catchment underlain by volcanic rock, Hydrol. Process., 24 2771-2783, 2010.

Jeanneau, L., Jaffrezic, A., Pierson-Wickmann, A.-C., Gruau, G., Lambert, T., and Petitjean, P.: Constraints on the Sources and Production Mechanisms of Dissolved Organic Matter in Soils from Molecular Biomarkers, Vadose Zone J., 13, 1539-1663, doi:10.2136/vzj2014.02.0015, 2014.

Jordan, T. E., Correll, D. L., and Weller, D. E.: Relating nutrient discharges from watersheds to land use and streamflow variability, Water Resour. Res., 33, 2579-2590, doi:10.1029/97WR02005, 1997.

Kirkby, M., Bracken, L., and Reaney, S.: The influence of land use, soils and topography on the delivery of hillslope runoff to channels in SE Spain, Earth Surf. Proc. Landforms, 27, 1459-1473, doi:10.1002/esp.441, 2002.

Kolbe T., Marçais J., Thomas Z., Abbott B.W., de Dreuzy J.R., Rousseau-Gueutin P., Aquilina L., Labasque, T., and Pinay G.: Dominance of local flows and extended transit times in shallow aquifers, J. Hydrol., in press, 2016.

Lambert, T., Pierson-Wickmann, A.-C., Gruau, G., Jaffrezic, A., Petitjean, P., Thibault, J. N., and Jeanneau, L.: DOC sources and DOC transport pathways in a small headwater catchment as revealed by carbon isotope fluctuation during storm events, Biogeosciences, 11, 3043-3056, doi:10.5194/bg-11-3043-2014, 2014.

Laudon, H., Berggren, M., Agren, A., Buffam, I., Bishop, K., Grabs, T., Jansson, M., and Kohler S.: Patterns and dynamics of dissolved organic carbon (DOC) in Boreal streams: the role of processes, connectivity, and scaling, Ecosystems, 14, 880-893, doi:10.1007/s10021-011-9452-8, 880-893, 2011.

Lê, S., Josse, J., and Husson, F.: FactoMineR: An R Package for Multivariate Analysis, J. Stat. Softw., 25, 1-18, 2008.

Lefebvre, S., Clément, J.-C., Pinay, G., Thenail, C., Durand, P., and Marmonier, P.: 15n-nitrate signature in low-order streams: effects of land cover and agricultural practices, Ecol. Appl., 17, 23332346, doi:10.1890/06-1496.1, 2007.

Li, Y., Yang, X., Cai, H., Xiao, L., Xu, X., and Liu, L.: Topographical Characteristics of Agricultural Potential Productivity during Cropland Transformation in China, Sustainability, 7, 96-110, doi:10.3390/su7010096, 2014.

Mérot, P. and Bruneau, P.: Sensitivity of bocage landscapes to surfaces run-off: application of the Kirkby index, Hydrol. Process. 7, 167-173, doi:10.1002/hyp.3360070207, 1993.

Meybeck, M. and Moatar, F. Daily variability of river concentrations and fluxes: indicators based on the segmentation of the rating curve, Hydrol. Process., 26, 1188-207, doi:10.1002/hyp.8211, 2012.

Moatar, F., Meybeck, M., Raymond, S., Birgand, F., and Curie, F.: River flux uncertainties predicted by hydrological variability and riverine material behavior, Hydrol. Process., 27, 3535-46, doi:10.1002/hyp.9464, 2013.

Molenat, J., Gascuel-Odoux, C., Ruiz, L., and Gruau, G.: Role of water table dynamics on stream nitrate export and concentration in agricultural headwater catchment (France), J. Hydrol., 348, 363-378, 2008.

Odgaard, M. V., Bøcher, P. K., Dalgaard, T., Moeslund, J. E., and Svenning, J.-C.: Human-driven topographic effects on the distribution of forest in a flat, lowland agricultural region, J. Geogr. Sci., 24, 76-92, doi:10.1007/s11442-014-1074-6, 2013.

Omernik, J. M., Abernathy, A. R., and Male, L. M.: Stream nutrient levels and proximity of agricultural and forest land to streams: Some relationships, J. Soil Water Conserv., 36, 227-231, 1981.

Parkin, T. B.: Soil microsites as a source of denitrification variability, Soil Sci. Soc. Am. J., 51, 1194-1199, 1987.

Pinay, G., Peiffer, S., De Dreuzy, J. R., Krause, S.,Hannah, D. M.,Fleckenstein, J. H., Sebilo, M., Bishop, K., and Hubert-Moy, L.: Upscaling Nitrogen Removal Capacity from Local Hotspots to Low Stream Orders' Drainage Basins, Ecosystems, 18, 11011120, 2015.

Ramankutty, N., Evan, A. T., Monfreda, C., and Foley, J. A.: Farming the planet: 1. Geographic distribution of global agricultural lands in the year 2000, Global Biogeochem. Cy., 22, GB1003, doi:10.1029/2007GB002952, 2008.

R Core Team: R: A language and environment for statistical computing. R Foundation for Statistical Computing, Vienna, Austria, http://www.R-project.org/ (last access: 22 March 2016), 2014.

Rockström, J., Steffen, W., Noone, K., Persson, Å., Chapin, F. S., Lambin, E. F., Lenton, T. M., Scheffer, M., Folke, C., Schellnhuber, H. J., Nykvist, B., de Wit, C. A., Hughes, T., van der Leeuw, S., Rodhe, H., Sörlin, S., Snyder, P. K., Costanza, R., Svedin, U., Falkenmark, M., Karlberg, L., Corell, R. W., Fabry, V. J., Hansen, J., Walker, B., Liverman, D., Richardson, K., Crutzen, P., and Foley, J. A.: A safe operating space for humanity, Nature, 461, 472-475, doi:10.1038/461472a, 2009.

Rosemond, A. D., Benstead, J. P., Bumpers, P. M., Gulis, V., Kominoski, J. S., Manning, D. W. P., Suberkropp, K., and Wallace, J. B.: Experimental nutrient additions accelerate terrestrial carbon loss from stream ecosystems, Science, 347, 1142-1145, doi:10.1126/science.aaa1958, 2015.

Sebilo, M., Mariotti, A., Mayer, B., and Pinay G.: Long term release of nitrate from agricultural plant-soil system, P. Natl. Acad. Sci. USA, 110, 18185-18189, doi:10.1073/pnas.1305372110, 2013. 
Seitzinger, S., Harrison, J. A., Böhlke, J. K., Bouwman, A. F., Lowrance, R., Peterson, B., Tobias, C., and Drecht, G. V.: Denitrification across landscapes and waterscapes: a synthesis, Ecol. Appl., 16, 2064-2090, doi:10.1890/10510761(2006)016[2064:DALAWA]2.0.CO;2, 2006.

Sidle, R. C.: Field observations and process understanding in hydrology: essential components in scaling, Hydrol. Process., 20, 1439-1445, doi:10.1002/hyp.6191, 2006.

Strahler, A. N.: Dynamic basis of geomorphology, Geol. Soc. Am. Bull., 63, 923-938, 1952.

Strayer, D. L., Beighley, R. E., Thompson, L. C., Brooks, S., Nilsson, C., Pinay, G., and Naiman, R. J.: Effects of Land Cover on Stream Ecosystems: Roles of Empirical Models and Scaling Issues, Ecosystems, 6, 407-423, doi:10.1007/PL00021506, 2003.

Thenail, C., Joannon, A., Capitaine, M., Souchère, V., Mignolet, C., Schermann, N., Di Pietro, F., Pons, Y., Gaucherel, C., Viaud, V., and Baudry, J.: The contribution of croprotation organization in farms to crop-mosaic patterning at local landscape scales, Agr. Ecosyst. Environ., 131, 207-219, doi:10.1016/j.agee.2009.01.015, 2009.

Thomas, Z., Molénat, J., Caubel, V., Grimaldi, C., and Mérot, P.: Simulating soil-water movement under a hedgerow surrounding a bottomland reveals the importance of transpiration in water balance, Hydrol. Process., 22, 577-585, doi:10.1002/hyp.6619, 2008.
Thomas, Z., Ghazavi, R., Merot, P., and Granier, A.: Modelling and observation of hedgerow transpiration effect on water balance components at the hillslope scale in Brittany, Hydrol. Process., 26, 4001-4014, doi:10.1002/hyp.9198, 2012.

Tye, A. M., Robinson, D. A., and Lark, R. M.: Gradual and anthropogenic soil change for fertility and carbon on marginal sandy soils, Geoderma, 207, 35-48, doi:10.1016/j.geoderma.2013.05.004, 2013.

Vitousek, P. M., Mooney, H. A., Lubchenco, J., and Melillo, J. M.: Human Domination of Earth's Ecosystems, Science, 277, 494 499, doi:10.1126/science.277.5325.494, 1997.

Yang, L., Chang, S. W., Shin, H. S., and Hur, J.: Tracking the evolution of stream DOM source during storm events using end member mixing analysis based on DOM quality, J. Hydrol., 523, 333341, doi:10.1016/j.jhydrol.2015.01.074, 2015.

Yeakley, J. A., Swank, W. T., Swift, L. W., Hornberger, G. M., and Shugart, H. H.: Soil moisture gradients and controls on a southern Appalachian hillslope from drought through recharge, Hydrol. Earth Syst. Sci., 2, 41-49, doi:10.5194/hess-2-41-1998, 1998.

Zabel, F., Putzenlechner, B., and Mauser, W.: Global Agricultural Land Resources - A High Resolution Suitability Evaluation and Its Perspectives until 2100 under Climate Change Conditions, PLoS ONE, 9, 1-12, doi:10.1371/journal.pone.0107522, 2014. 